J. Perinat. Med. $11(1983) 243$

\section{Clinical significance of short-term variability computed from heart-rate waveforms}

\author{
D. Maulik*, V.Saini*, S. T.Zigrossi** \\ * Department of Obstetrics and Gynecology and \\ ** School of Nursing, Strong Memorial Hospital, Rochester, USA
}

\section{Introduction}

It has been increasingly appreciated in recent years that the short-term variability (STV) of the baseline fetal heart rate (FHR) represents one of the most significant predictors of fetal well-being in labor [2]. The variability is produced by the continuous dynamic interaction that exists between the fetal sympathetic and parasympathetic cardioregulatory mechanisms, and thus requires continuing existence of a normally functioning fetal central nervous system and an intact responsiveness of the fetal heart [5]. However, reliable quantification of STV by visually assessing the FHR waveforms produced by commercial fetal monitors is difficult and suffers from inaccuracies. Controlled studies involving known experts have shown low correlation between visual subjective and stochastic quantification of STV [1]. It is obvious that if STV is to be a consistently reproducible parameter of electronic fetal monitoring, it should be objectively quantified. YEH, et al., [8], have described a quantitative measure of STV called the Differential Index, which is defined in terms of the standard deviation of the differences between adjacent $R-R$ time intervals in the fetal electrocardiogram. In order to compute the adjacent R-R time intervals, the fetal EKG is generally processed by a computer, and the complexity of these analyses has limited the clinical application of this index.

In order to circumvent this problem, we have developed, and described elsewhere [4, 7], a

\section{Curriculum vitae}

DEBABRATA MAULIK was born on March 3,1939 and finished Medical Graduation from the University of Calcutta, India, in 1962. In 1967 he was admitted as MRCOG, England, and worked as lecturer at the University of London from 1970 to 1976, where he obtained a Ph. D. in 1975. He was admitted to the American Board of Obstetrics \& Gynecology in 1979, was Director of the Perinatal Division at SUNY Buffalo (Deaconess Hospital) from 1976-1980, and is currently attending Perinatologist at Strong Memorial Hospital, University of Rochester.

method for computing STV from the slowly varying fetal heart rate waveform rather than from the relatively rapidly varying fetal electrocardiogram. This paper describes the clinical utilization of this technique, and presents results indicative of the significance of STV in intrapartal assessment.

\section{Methodology}

As described elsewhere [4, 7], we define STV during some fixed time-window as the corrected maximum deviation of the instantaneous fetal heart rate from the heart-rate trend. This method was found to correlate excellently with the Differential Index, but proved to be much more efficient 


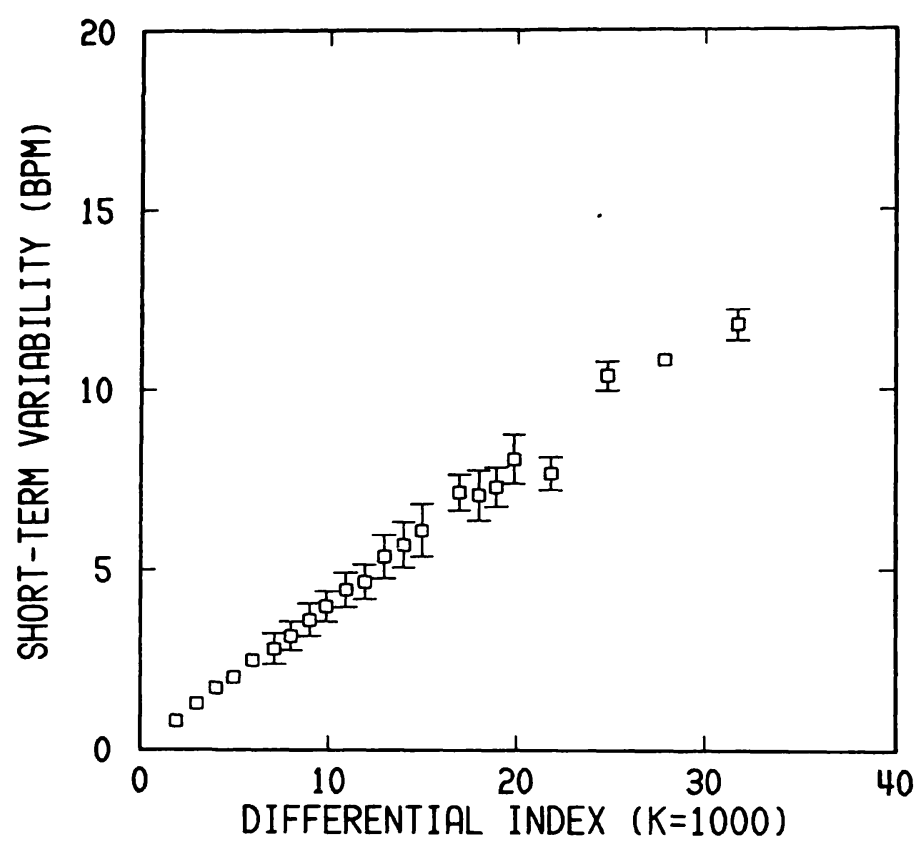

Fig. 1. Correlation between short-term variability computed from the fetal heart-rate waveforms (STV) and the differential Index.

in terms of computational requirements. Fig. 1 demonstrates the correlation between STV computed in this manner, and the Differential Index for 3 hours of fetal data.

The clinical significance of STV computed by this method was evaluated retrospectively in a patient population monitored during labor. FHR was monitored by means of a scalp electrode, and contractions by an external tocotransducer using a commercial fetal monitor (COROMETRICS model 112). The signals were digitized onto IBM-compatible 9-track digital magnetic tape using a PERKIN-ELMER Model 7/32 minicomputer at a sampling rate of 240 milliseconds. The digitized signals were then analyzed off-line for STV and FHR. For each patient, baseline periods were visually identified, subject to the criterion that they begin at least 30 seconds after the end of a contraction or periodic heart rate pattern, and end at least 30 seconds before the next contraction or periodic heart rate pattern. Baseline periods in which adjacent instantaneous FHR values differed by more than 15 b.p.m. for more than 1 percent of the time were excluded to avoid artifactual epidsodes. The mean FHR and STV for each of these baseline periods were computed. Let $\mathrm{H}_{\mathrm{ij}}$ denote the mean $\mathrm{FHR}$, and $\mathrm{V}_{\mathrm{ij}}$ denote the mean STV for the $j^{\text {th }}$ baseline period for the $i^{\text {th }}$ patient, and $\mathrm{N}_{\mathrm{i}}$ be the number of baseline periods for that patient. Then, for each patient, the following were computed:

$$
\begin{aligned}
V_{i_{\text {max }}} & =\operatorname{MAX}\left(V_{i j}\right), j=1 \text { to } N_{i} \\
V_{i_{\text {mean }}} & =\operatorname{MEAN}\left(V_{i j}\right), j=1 \text { to } N_{i} \\
V_{i_{\text {min }}} & =\operatorname{MIN}\left(V_{i j}\right), j=1 \text { to } N_{i} \\
V_{i_{\text {std }}} & =\operatorname{STD.-DEVIATION~}\left(V_{i j}\right), j=1 \text { to } N_{i} \\
H_{i_{\text {mean }}} & =\operatorname{MEAN~}\left(H_{i j}\right), j=1 \text { to } N_{i}
\end{aligned}
$$

In other words, $V_{i_{\max }}, V_{i_{\text {mean }}}$, and $V_{i_{\min }}$ are the maximum, mean and minimum baseline STV values for the $i^{\text {th }}$ patient, $V_{i s t d}$ is the standard deviation of baseline variabilities for that patient, and $\mathbf{H}_{\mathbf{i}_{\text {mean }}}$ is the mean baseline FHR.

For each patient, about 600 clinical variables encompassing antepartum history to neonatal outcome were entered into the computer using an optical technique described elsewhere [6]. These data were used to comprehensively score neonatal outcome using HOBEL's neonatal risk assessment scheme [3].

\section{Results}

The population comprised 45 patients with gestational ages ranging from 30 to $\mathbf{4 2}$ weeks. Values of $V_{i_{\text {mean }}}$ ranged from 1.21 b.p.m. to 6.47 b.p.m., with a median value of 2.75 b.p.m. The highest value of $V_{i_{\text {std }}}$ was 2.57 b:p.m. Based on the median value of $V_{i_{\text {mean }}}$, the patient population was divided into a low-variability group $\left(\mathrm{V}_{\mathrm{i}_{\text {mean }}} \leqslant 2.75\right.$ b.p.m.: 22 patients), and a highvariability group $\left(\mathrm{V}_{\mathrm{i}_{\text {mean }}}>2.75\right.$ b.p.m.: 23 patients). Application of the STUDENT's t-test on values of $V_{i j}$ for these two populations showed them to differ significantly in baseline variabilities $(P<0.001)$. This is also indicated by the fact that values of $V_{i_{\text {std }}}$ are much smaller than the range of values of $V_{i_{\text {mean }}}$. It is therefore justified to classify patients into low- and high-variability groups based on $\mathrm{V}_{\mathbf{i}_{\text {mean }}}$.

Neonatal outcome in each of these patients was evaluated by means of HOBEL's neonatal risk assessment score. It was arbitrarily decided to consider a risk score less than or equal to 75 as 


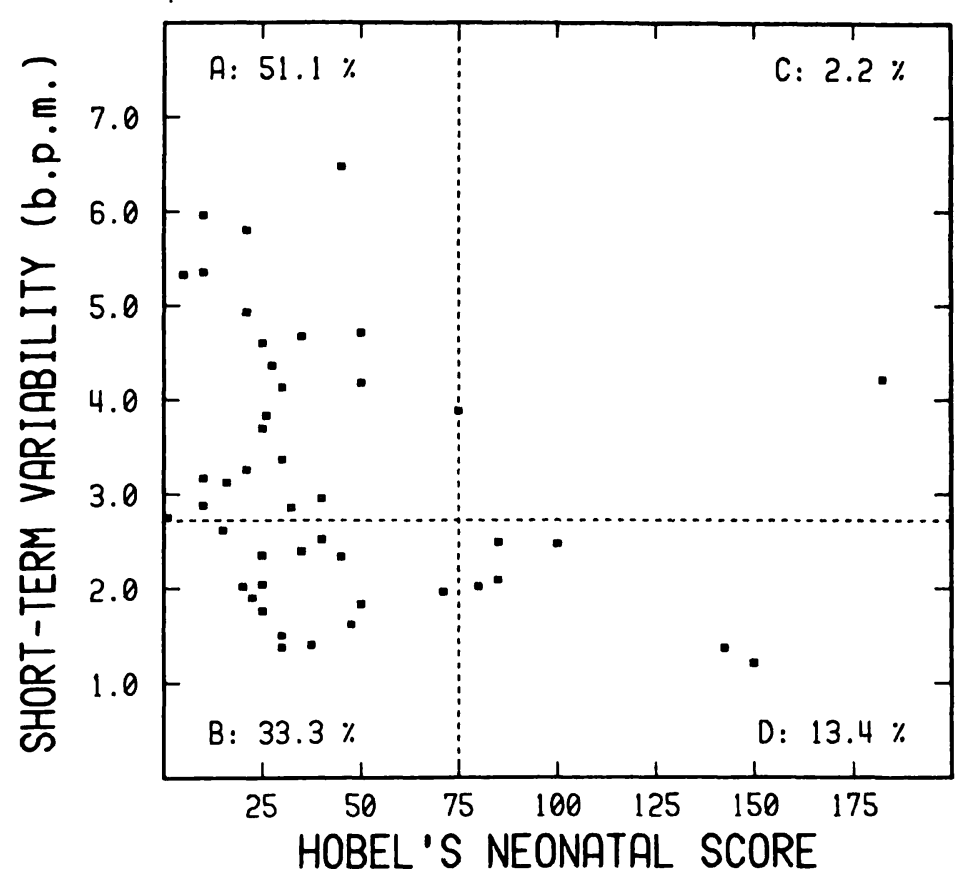

Fig. 2. Scatter diagram showing the association between STV and HOBEL's neonatal risk score. The regions represent: (A): true security; (B) false alarm; (C) false security; (D): true alarm.

low-risk, and scores greater than 75 as belonging to the high-risk category.

Fig. 2 is a scatter diagram showing the incidence of high- and low-variability in the low- and high-risk neonatal outcome groups. $28.7 \%$ of the lowvariability population resulted in poor outcome, while only one patient out of $23(4.3 \%)$ in the high-variability population had a high-risk HOBEL score. 6 out of 7 patients in the high-risk outcome group were correctly predicted by low STV. However, 15 out of the total of 45 patients fell into the low-risk outcome group inspite of showing low STV, resulting in an over-all false alarm rate of $33.3 \%$. Nevertheless, STUDENT's t-test analysis on the high- and low-risk population showed that their mean short term variabilities were different at the $5 \%$ level $(P=0.026)$. The mean short term variabilities of the low- and high-risk groups were 3.31 and 2.27 b.p.m. respectively.

Tab. I lists how the low- and high-variability groups performed when APGAR scoring was used for neonatal assessment. Again, it is observed that the low-variability group was associated with a higher incidence of poor 1 -minute and 5-minute APGAR scores than was the high-variability group.
Tab. I. Table showing incidence of low APGAR scores in low- and high-variability groups as percentages of total number of patients in that group.

\begin{tabular}{|c|c|c|}
\hline & $\begin{array}{l}\text { LOW } \\
\text { VAR }\end{array}$ & $\begin{array}{c}\text { HIGH } \\
\text { VAR }\end{array}$ \\
\hline $\begin{array}{c}1-\text { min Apgar } \\
5 \text { or less }\end{array}$ & $22.7 \%$ & $4.3 \%$ \\
\hline $\begin{array}{c}5-\mathrm{m} \text { in Apgar } \\
5 \text { or less }\end{array}$ & $9.1 \%$ & $0.0 \%$ \\
\hline
\end{tabular}

The relationship between baseline FHR and baseline STV for all baselines monitored is shown in Fig. 2. A marked decrease of STV is observed as baseline FHR values increase (coefficient of correlation $=-0.8545$ ).

The relationship between $V_{i_{\text {mean }}}$ and neonatal gestational age was also investigated, and is shown by the scatter diagram in Fig. 3 . It is seen that for gestational ages more than 34 weeks, high-risk cases were associated with the lowest values of STV.

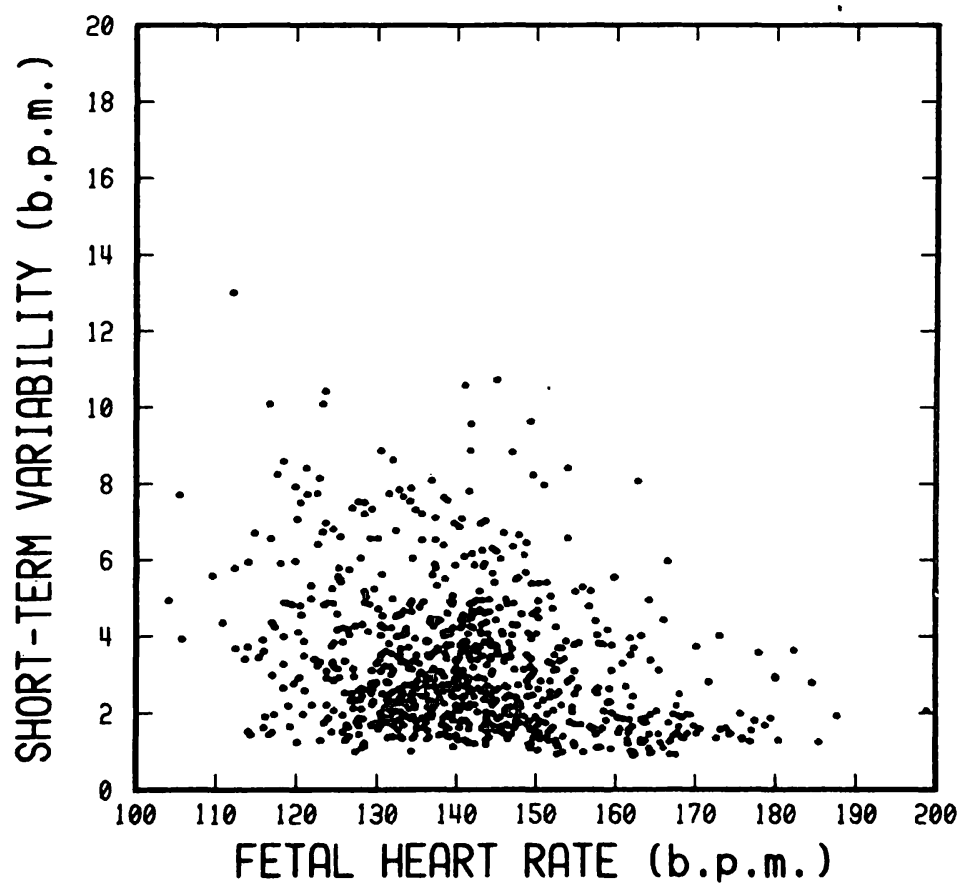

Fig. 3. Scatter diagram showing baseline STV in relation to baseline fetal heart-rate. Coeff. of correlation $=-0.8546$. 
Of the 45 patients included in this study, 11 $(24.4 \%)$ were administered meperidine in conjuntion with phenergan, $15(33.3 \%)$ were given only meperidine and $4(8.89 \%)$ only phenergan. The time durations by which administration of meperidine preceded delivery ranged from 0.3 to 14.4 hours $($ mean $=4.85$, std. -dev. $=4.21)$. For phenergan these figures were 0.42 to 14.4 hours (mean $=5.04$, std.. dev. $=4.18)$. A slight depression in STV was observed in these patients relative to those that were not administered either meperidine or phenergan (3.01 b.p.m. vs. 3.42 b.p.m.), but the difference was not statistically significant $(P=0.32) .4$ patients $(8.89 \%)$ were administered morphine from 9.5 to 19.0 hours (mean $=13.36$, std.-dev. $=4.04$ ) before delivery. This was seen to be associated with a slight and statistically insignificant increase in STV over those not adminstered morphine (3.88 b.p.m. vs. 3.07 b.p.m., $P=0.37$ ).

\section{Conclusion}

Several methods have been proposed to quantifiy STV. The most widely accepted of these in the

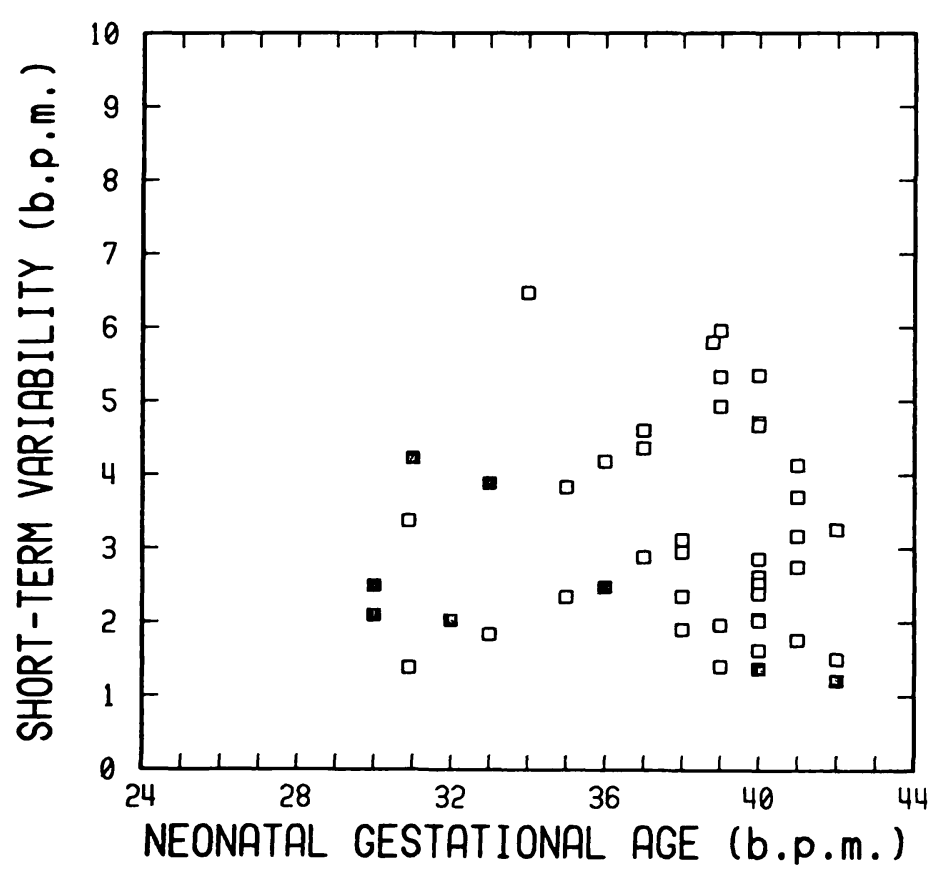

Fig. 4. Baseline STV as a function of neonatally assessed gestational age. $\square=$ low-risk group; - high-risk group.
DIFFERENTIAL INDEX proposed by YEH \& HON [8]. This index is based i 9 the statistics of $R-R$ time-interval differences. Its computation requires either the use of special hardware to digitize these time-intervals, or computer processing of the fetal electrocardiogram for $R$-wave detection and interval computation. This has virtually limited its use to the research environment.

$R-R$ interval information is present in the instantaneous FHR waveform produced by commercially available monitors, since instantaneous FHR is merely the reciprocal of R-R time intervals. However, computation of STV therefrom is complicated by the fact that this waveform does not explicitly identify the exact instants of time when heart-beats occur.

We have previously described $[4,7]$ a method for quantifiying STV in terms of beats per minute from the slowly-varying instantaneous FHR waveform rather than from the relatively rapidlyvarying fetal electrocardiogram. Results produced by this method were found to correlate excellently with the DIFFERENTIAL INDEX, but the required computation time was reduced drastically compared with computation of the DIFFERENTIAL INDEX from the fetal electrocardiogram [7]. Further, this method can be readily implemented on a small labor-room microcomputer without any additional hardware, and results can be made available in real-time.

Using our method for quantifiying STV, this study confirms that low STV is associated with poor neonatal outcome. We have used a comprehensive index of neonatal assessment [3] rather than the APGAR scoring system in order to more reliably study the significance of STV. Like other FHR monitoring indices, it is a sensitive but not very specific indicator of fetal compromise. It appears to be particularly useful as an additional diagnostic tool at gestational ages greater than 34 weeks. These results form the basis for an on-going prospective study involving more patients and including the time-sequential effects of such factors as medications and fetal rest-activity cycles to more thoroughly evaluate the significance of STV as an indicitor of fetal wellbeing. 


\section{Summary}

The significance of short-term variability (STV) of the baseline fetal heart rate (FHR) as a prime indicator of fetal well-being is well recognized. It is obvious that for consistently reliable assessment of short-term variability, objective quantification is a necessity. This paper presents a retrospective clinical evaluation of a new technique of STV quantification in terms of beats per minute derived from the slowly varying instantaneous FHR waveform rather than from the relatively rapidly varying fetal ECG. FHR signals from 45 patients, internally monitored during labor, were digitized onto IBM-compatible 9-track digital magnetic tape using a PERKIN-ELMER model $7 / 32$ minicomputer at a sampling rate of 240 milliseconds. The digitized signals were then analyzed off-line for STV and FHR. For each patient about 600 clinical variables were entered into the computer and these data were utilized to comprehensively evaluate the neonatal outcome according to HOBEL's neonatal risk assessment system.

The values of mean STV ranged from 1.21 b.p.m to 6.47 b.p.m. with a median value of 2.75 b.p.m., which was used to divide the patient population into a low-variability $(\leqslant 2.75$ b.p.m.) and a high-variability ( $>2.75$ b.p.m.) group. This was found to be justified as the STUDENTS's t-test on mean baseline STV values for these two populations showed them to differ significantly ( $P<0.001)$.

Analysis of the results (Fig. 1) showed that $28.7 \%$ of the low-variability population were associated with a poor outcome compared with $4.3 \%$ in the high-variability group. However, there was a false alarm rate of $33.3 \%$. STUDENT's t-test on the high- and low-risk populations showed that their mean baseline STV values were different at the $5 \%$ level $(P=0.026)$. It was also observed that the low-variability group was associated with a higher incidence of poor 1-minute and 5-minute APGAR scores than was the high-variability group. A marked reduction of STV was also noted (Fig. 2) as baseline FHR values increased (coefficient of correlation $=-0.8546$ ). In addition, it was shown that for gestational ages more than 34 weeks, high-risk cases were associated with the lowest values of STV.

The study demonstrated the successful clinical applicability of a new and objective method of STV quantification which can be implemented in a fraction of the time required to compute the DIFFERENTIAL INDEX from the fetal ECG without special time-ncoding hardware. The method can be implemented in real time on a microcomputer. It also confirmed that low STV was associated with poor neonatal outcome.

Keywords: Fetal-Monitoring, quantitative computer HOBEL-Risk-Score, short-term beat-to-beat baseline variability

\section{Zusammenfassung}

Zur klinischen Bedeutung von aus Herzfrequenzkurven berechneten Kurzzeitschwankungen

Die Bedeutung von Kurzzeitschwankungen bzw. Oszillationen der Basalkurve der fetalen Herzfrequenz (FHR) als wichtiger Indikator für den fetalen Zustand ist allgemein anerkannt. Es liegt auf der Hand, daß für eine wirklich reliable Auswertung von Kurzzeitschwankungen deren objektive Quantifizierung notwendig ist. In dieser Arbeit berichten wir über eine retrospektive klinische Studie, die auf einer neuen Technik zur Quantifizierung von Kurzzeitschwankungen basiert. Die Amplitude wurde in der Anzahl der Schläge pro Minute (bpm) ausgedrückt. Wir bevorzugten die Ableitung aus einer sich nur langsam ändernden fetalen Herzfrequenzkurve gegenüber einem sich relativ schnell verändernden fetalen EKG. Bei 45 Patientinnen wurde unter der Geburt eine interne FHR-Registrierung vorgenommen. Die Signale wurden auf einem IBM-kompatiblen 9-Kanal-Digital-Magnetband unter Verwendung eines Minicomputers (Modell 7/32 von PERKIN-ELMER) in 240 Millisekunden-Blöcken digitalisiert. Aus den digitalisierten Signalen wurden dann offline die Kurzzeitschwankungen und die FHR bestimmt. Für jeden Patienten wurden ungefähr 600 klinische Variable in den Computer eingegeben und diese Daten eingesetzt $\mathrm{zu}$ einer grundlegenden Erfassung des neonatalen Zustandes unter Berücksichtigung des Systems nach HOBEL zur Bestimmung des neonatalen Risikos.

Die mittleren Oszillationsamplituden lagen zwischen $1,21 \mathrm{bpm}$ und $6,47 \mathrm{bpm}$. Der Medianwert von 2,75 bpm wurde eingesetzt, um das Patientenkollektiv in eine Gruppe mit niedriger Variabilität $(\leqslant 2.75 \mathrm{bpm})$ und eine Gruppe mit hoher Variabilität $(>2.75 \mathrm{bpm})$ aufzuteilen.

Schlüsselwörter: Fetale Überwachung, Kurzzeitschwankungen der Basalfrequenz über Schlag-zu-Schlag-Registrierung, quantitativer Risiko-Score per Computer nach HOBEL.
Im t-Test ergab die Prüfung der mittleren Basalfrequenzschwankungen für diese beiden Gruppen einen signifikanten Unterschied $(p<0,001)$ was unsere Vorgehensweise rechtfertigt.

Die Analyse der Ergebnisse (Fig. 1) zeigt, daß 28,7\% der Kinder aus der Gruppe mit niedriger Variabilität in einem schlechten neonatalen Zustand waren gegenüber nur 4,3\% aus der Gruppe mit hoher Variabilität. Es gab jedoch eine falsch positive Rate von $33,3 \%$. Im $t$-Test ergab die Prüfung der mittleren Basalfrequenzschwankungen aus der Gruppe mit hohem und aus der mit geringem Risiko Unterschiede auf dem $5 \%$-Niveau $(p=0,026)$. Wir konnten auch beobachten, daß in der Gruppe mit niedriger Variabilität häufiger schlechte APGAR-Werte 1 bzw. 5 Minuten post partum festgestellt wurden. Eine erhebliche Reduzierung von Kurzzeitschwankungen wurde auch beim Anstieg der Basalfrequenz gefunden (Korrelationskoeffizient $=-0,8546)$. Zusätzlich konnten wir zeigen, daß bei einem Gestationsalter von mehr als 34 Wochen Fälle mit einem hohen Risiko die niedrigsten Werte für Kurzzeitschwankungen aufwiesen.

Die Untersuchung beweist die erfolgreiche klinische Anwendbarkeit einer neuen objektiven Methode zur Quantifizierung von Kurzzeitschwankungen, die zu ihrer Ausführung nur einen Bruchteil der Zeit erfordert, die die Erstellung von Differentialindices aus dem fetalen EKG kostet und die ohne ein speziell verschlüsseltes Hardware auskommt. Die Methode kann im Echt-Zeit-Verfahren auf einem Mikrocomputer ausgefuihrt werden. Es wurde auch bestätigt, daß geringe Oszillationsamplituden mit einem schlechten neonatalen Zustand einhergehen. 


\section{Résumé}

Signification clinique de la variablilité a court terme étudiée par ordinateur à partir des impulsions du rythme cardiaque

La signification de la variabilité à court terme (V.C.T.) du rythme cardiaque fœtal de base (R.C.F.) comme indicateur de premier ordre du bien-être fœtal est bien reconnue.

Il est clair que pour une évaluation solide de la variabilité à court terme une quantification objective est nécessaire. Cet article rapporte une évaluation clinique rétrospective d'une nouvelle technique de quantification de la V.C.T. en terme de battements par minute dérivés des impulsions à variations instantanées lentes du R.C.F. plutôt que de l'E.C.G. fœtal à variations relativement rapides. Les signaux du R.C.F. chez 45 patientes, monitorisés par voie interne pendant le travail ont été enregistrés sur une platine à bande magnétique numérique à 9 pistes IBM compatible en utilisant un mini-ordinateur modèle $7 / 32$ PERKIN-ELMER à une fréquence étalon de 240 millisecondes. Les signaux numériques ont été ensuite analysés off-line pour la V.C.T. et le R.C.F.

: Pour chaque patiente environ 600 variables cliniques ont été accumulées dans l'ordinateur et ces données ont été utilisées pour évaluer de façon compréhensible le devenir néonatal selon le système d'appréciation du risque néonatal de HOBEL.

Les valeurs de la V.C.T. moyenne s'échelonnent de 1,21 b.p.m. à 6,47 b.p.m. avec une médiane de 2,75 b.p.m.; ces valeurs ont été utilisées pour répartir la population des patientes en groupe de variabilité faible $(\leqslant 2,75$ b.p.m.) et en groupe de variabilité élevée $(>2,75$ b.p.m.). Cette répartition a été validée par le t. test des étudiants qui mantre que les valeurs de la V.C.T. moyenne de base pour ces deux populations, diffèrent de façon significative $(P<0,001)$.

L'analyse des résultats (Fig. 1) montre que $28,7 \%$ de la population avec variabilité faible est associée à un devenir médiocre en comparaison des $4,3 \%$ dans le groupe avec variabilité élevée.

Cependant, il y a un pourcentage de faux positifs de $33,3 \%$. Le t. test des étudiants sur les populations à haut et à bas risques montre que les valeurs basales moyennes de la V.C.T. sont différentes au seuil de $5 \%$ $(\mathbf{P}=0,026)$.

On a observé également que le groupe avec une variabilité basse est associé à une incidence plus élevée de scores d'APGAR bas à une minute et à cinq minutes que dans le groupe à variabilité élevée. Une diminution importante de la V.C.T. a également été notée (Fig. 2) en même temps que le R.C.F. des base augmente (Coefficient de corrélation $=-0,8546$ ).

En outre, il a été montré que pour les termes gestationnels supérieurs à 34 semaines les cas à haut risques sont associés au valeurs de la V.C.T. les plus basses.

Cette étude démontre la possibilité d'utilisation clinique valable d'une nouvelle méthode objective de quantification de la V.C.T. qui peut être obtenue en une fraction de temps nécessaire pour analyser par ordinateur l'index différentiel à partir de l'E.C.G. fœtal sans programmation spéciale du Hardware.

La méthode peut étre réalisée en temps réel sur un microordinateur' L'étude confirme également que les faibles V.C.T. sont associées avec un devenir néonatal médiocre.

Mots-clés: Court terme, battement à battement, fréquence de base, monitoring fœtal, ordinateur, score de risque de HOBEL, variabilité.

Acknowledgement: This research was partially supported by a gift from the estate of RICHARD W. GOODE and MAY STONE GOODE.

\section{Bibliography}

[1]ESCARCENA, L., R. D. MCKINNEY, R. DEPP: Fetal baseline heart rate variability estimation: I. Comparison of clinical and stochastic quantification techniques. Amer. J. Obstet. Gynec. 135 (1979) 615

[2]FREEMAN, R. K., T. J. GARITE: Fetal heart rate monitoring. Williams \& Wilkins, Baltimore-London 1981

[3] HOBEL, C. J.: Identification of the patient at risk. In Perinatal Medicine Management of the high risk fetus and neonate. In: BOLOGNESE, R. T., R. H. SCHWARZ (eds.). Williams \& Wilkins, Baltimore/ London 1977

[4] MAULIK, D., V. D. SAINI, S. T. ZigRosSI:A new technique for short-term variability quantification and its correlation with neonatal outcome. Proc. 1 st. Internat. Symp. on Computers in Perinat. Med. (1981) 94

[5] RENOU, P., N. WARNWICK, C. WOOD: Autonomic control of fetal heart rate. Amer. J. Obstet. Gynec. 105 (1969) 949
[6]SAINI, V. D., D. MAULIK: A new optically readable scoring system for comprehensive computerization of clinical information. Proc. 1st. Internat. Symp. on Computers in Perinat. Med. (1981) 39

[7]SAINI, V. D., D. MAULIK: Computation of shortterm fetal heart rate variability from heart-rate waveforms. Computers in Biol. and Med. 12 (1982) 81

[8] YEH, S. Y., A. FORSYTHE, E. H. HON: Quantitation of fetal heart rate beat-to-beat interval differences. Obstet. and Gynec. 41 (1973) 355

Received March 5, 1983. Accepted April 9, 1983.

Debabrata Maulik, M.D., P̈h.D., Department of Obstetrics \& Gynecology, University of Rochester Medical Center, Box 668, Strong Memorial Hospital, 601 Elmwood Ave., Rochester, N.Y. 14642, USA 